\title{
Application possibilities of blockchain technology in the energy sector
}

\author{
Anna Zielińska ${ }^{1, *}$ \\ ${ }^{1}$ AGH University od Science and Technology, Krakow, Poland
}

\begin{abstract}
Blockchain is a block chain technology that makes it possible to send and store information in a distributed way, creating a decentralized data register. The article presents the applications of blockchain technology in the field of power engineering, among others for use in the area of settlements on the electricity market. The work shows the possibilities of using and using block chains to describe the purchase and sale, generation and management of electricity. The work describes aspects of technology that allow partial or complete decentralization of the process. The article also shows how such transactions could be carried out automatically and without supervision - giving certainty of pre-established rules, rules and assumptions.
\end{abstract}

\section{Introduction}

Today, a relatively long chain of intermediaries is involved in the electricity market and the energy trading process, from the manufacturer to the end customer. Is it possible to establish direct contacts between these two market players in the case of using Blockchain? Why the blockchain market for energy? These questions have been on the market for some time. The development of new technologies, meeting the expectations of users, the fight for clients are just some of the features that make the energy sector more and more interested in the implementation of Blockchain technology. In the largest energy companies in R \& D units more and more time is devoted to analyzing the possibilities of using Blockchain technology and the first pilot projects are carried out [1]. So as to develop the possibilities of using and using Blockchain to settle transactions on the energy market.

\section{Architecture of blockchain technology}

Blockchain systems may seem complicated, but they can be easily understood by examining each component of technology individually. Blockchain uses well-known IT mechanisms (distributed networks), as well as cryptography (hash technology, digital signatures, public / private keys) connected, among others, to with financial solutions (such as bank accounts, account books) [2].

Blockchain uses these cryptographic concepts very intensively and effectively. The first of these is the creation of unique and unambiguous "fingerprints" of data using one-way hash functions (so-called hash functions) [3]. The second important component of the blockchain technology is asymmetric cryptography that allows to secure the exchange of information, or even to encrypt information exchanged between two parties, without the need for the parties to agree on one common security key $[3,4]$. The third element from the world of cryptography adapted by blockchain technology is time marking, and providing unique blockchain features - consensus mechanisms and smart contracts.

By combining the components described so far: hash functions, cryptography, time stamping, the mechanism of consensus and smart contracts into one entity, we obtain the blockchain technology we know today [4].

\footnotetext{
*Corresponding author: azielinska@agh.edu.pl
} 
When describing the blockchain much easier, we can say that it is called a block chain that is capable of storing and transmitting various time stamped information in a distributed manner. This information is compiled in data blocks that are parts of the whole chain. Such a system can create a completely decentralized register or database [2]. This distributed database, based on a peer-to-peer network (P2P), has no highlighted central node, or any "super administrator", so that the blockchain does not have a single point of failure. In addition, the mechanism of consensus and continuous verification of records, secures the transaction system against abuse and other types of manipulation [3].

\section{Blockchain in the power sector}

Due to the above-mentioned aspects of technology, blockchain seems to be a very good solution that can provide, for example, decentralized data storage, payment and transaction verification, conclusion of the so-called smart-contracts and liquidation of intermediaries in business matters [1].

How to relate this to the power industry? Blockchain is a technology that is great for settling transactions on the energy market, carried out between energy producers and consumers [3].

By using block chains, sales and purchase of electricity could be carried out directly and autonomously between generators and energy consumers. Such a settlement model results in partial or total decentralization, because some of its solutions would not require the operation of any central supervisory unit mentioned earlier. Such transactions could be automatically based on predefined rules and rules. The solution would be possible thanks to the use of the so-called smart contracts [5].

Smart contract is a contract or set of rules governing business transactions [6]. This is another advance in blockchain technology that allows you to switch from the financial transaction protocol to tools that will automatically implement contract terms, minimizing the risk of error [5]. The aim of smart agreements is to provide higher security compared to traditional contracts while reducing costs and delays. Such a transaction is stored in a single block of the entire blockchain and performed automatically within the transaction $[4,5,6]$. The most important feature of smart contracts is their ability to use and cooperate with multiple blockchain chains. This means that one checked rule can have its base in one blockchain network and another one in another. In other words, smart contracts can be treated as computer programs that execute contracts based on rules agreed by individual parties to these contracts [5]. However, to perform a transaction based on a smart contract, it is necessary to have cryptocurrencies that allow you to enter into a contract, send it to a blockchain, where it will be automatically confirmed by contractors [4]. When traditional contracts contain the principle of agreement between the parties, intelligent contracts administer the rules of the contract, controlling the transfer of cash or value using a specific code [7].

Smart contracts may resemble popular, widely available applications, but the key difference is that they are characterized by greater automation - input data is important for the contract to exchange values [8]. The idea of settling the purchase and sale of electricity using blockchain technology should operate on the basis of a platform, system or the aforementioned application dedicated to these activities. Every customer and electricity generator would be able to register using the platform and thus become its user. Users would have to have appropriate intelligent energy meters installed, working with the platform, so that information about the energy produced, generated and introduced into the grid would be saved and entered into individual blocks of the chain. Such logging would allow logging of the entire history related to the consumption and generation profile for each individual user. Additionally, the kept register would have information on all power flows in the network and transactions made, thanks to which the created database of 
operations together with their entire history would be updated on an ongoing basis. According to the principle of blockchain technology, transactions would be disseminated and verified between individual network nodes. According to the rules of operation, the database would not provide for any changes to the information collected [4].

Thanks to the use of the P2P network and the combination of activities through the use of smart contracts, purchase and sale transactions could be carried out directly between all users registered on the platform. The algorithm would be the initiator of individual transactions, which would be performed on the basis of strictly defined assumptions and rules for their conduct. Thanks to this, the energy trading would be so automated that the settlements would be carried out automatically considering all assumptions given by individual users. Thanks to this, the balance between the generation and the demand for electricity in local power grids could be constantly maintained. The network could be largely managed by the blockchain platform itself [4].

Such flexible functionality of the blockchain network obtained thanks to smart contracts is today a great promise of completely new, truly innovative solutions based on blockchain [3].

The second big possibility of using blockchain technology is the service of the charging process for electric cars. Electromobility is one of the most current development trends. For European Union countries, including Poland, electromobility is a great challenge not only social and economic but also engineering and process. The large-scale introduction of the electric vehicle fleet (EV) is directly related to the impact on the lives of citizens and the functioning of the Polish economy sectors. The increase in the number of electric cars will be visible in the domestic power sector, affecting all its subsectors: manufacturing, transmission and distribution.

Blockchain technology and the use of P2P networks also have great potential in this aspect of development. Using smart contracts it would also be possible to support the EV charging process. The process could also be done on the basis of an application that would collect all data relating to the entire process. What's more, the whole blockchain could additionally participate in another aspect of the development of electromobility. This is about the impact on the operation of the power system using the Vehicle to Grid technology (V2G) which will improve the energy efficiency of distribution and distribution network operation with the use of energy reservoirs located in electric vehicles. Thanks to this, it will be possible to use the stored energy in the area of reactive power compensation and improvement of the quality parameters of electricity [9].

The charging process - corresponding to the purchase of energy and V2G technology corresponding to the mechanisms of purchase and sale, perfectly fits into the use of blockchain. All transaction data and the process of settlement and payment could be collected and stored on the blocks. Thus creating a decentralized information exchange platform.

The assessment of the impact of electromobility on the power system and on all environmental and social aspects will contribute to introducing a fleet of electric vehicles into the national economy in a controlled and effective manner. While in the initial phase of electromobility development the impact on energy will be low, it is assumed in 2025 . a million electric cars the way they are integrated into the system will determine the stability of the National Power System [10].

Blockchain and consideration of potential areas in which it would be possible to use it in the energy sector, cannot do without mentioning the traceability of the origin of energy resources [5]. This is about providing information under the Act [11] on the structure of fuels and other primary energy carriers used to generate electricity, and the impact of electricity produced and sold on the environment, in terms of emissions of carbon dioxide, sulfur dioxide and nitrogen oxides, dusts and radioactive waste [5]. 
From the perspective of the blockchain idea, it seems possible to use technology in the process of unambiguous determination of energy, i.e. to assign its unchangeable attributes of origin and parameters affecting the environment. The most important change in this area would be the necessity to register emission and environmental indicators in real time and to correlate this information with the registration of the level of electricity generation by metering and billing devices. Obviously, all measuring sources would have to be covered by such a measuring mechanism, taking into account the different emissivity specifity for carbon, gas and renewable carriers [5].

A model of collecting and presenting data on the structure of fuels and environmental impact could be used in an automatic manner to present information required by law in the reporting data. Such an energy tracking model could be used for both large-scale and local power engineering, appropriate for distributed energy, for example energy clusters.

Blockchain technology can be considered as the basis for the transformation of the power sector towards dispersed energy sources introducing a decentralized model of the sector's functioning. In addition to the above-described implementations, there are many ways to apply technology in this part of the economy: through electricity generation, distribution and sales, settlements in the peer-to-peer P2P system, data exchange platforms between users of the energy system (Fig.1.). In addition, certification (marking) of energy from renewable energy sources, support of systems related to car charging, systems for switching vendors, selected elements of microgrid management as well as support for decentralized information exchange platform (eg between transmission and distribution system operators and recipients) [12].

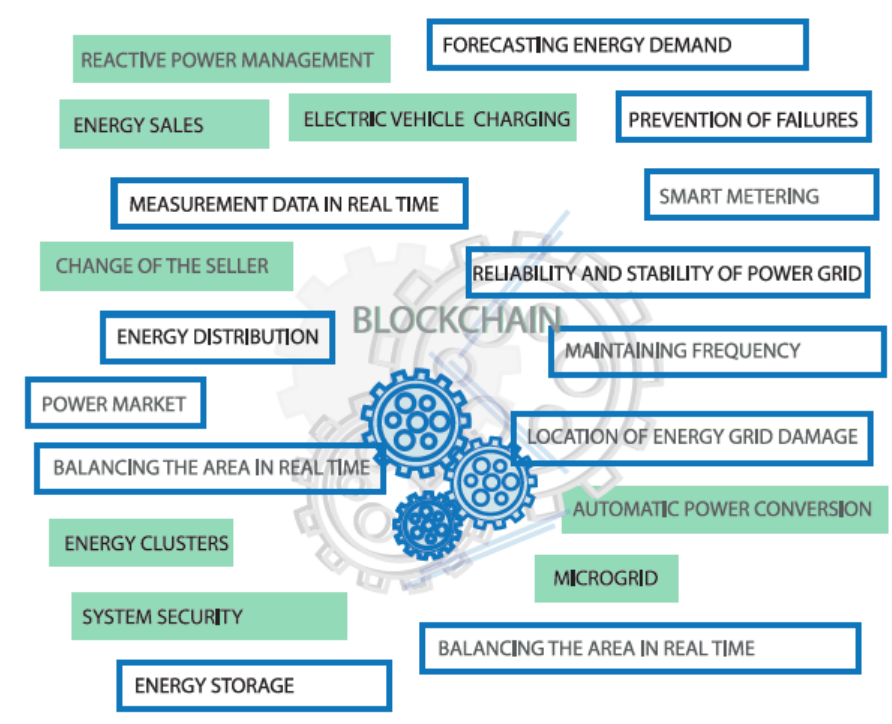

Fig.1. Possibilities of using blockchain in the energy sector

\section{Limiting the use of blockchain}

The adopted possibilities of using blockchain are the use of the great potential that this technology possesses, which undoubtedly may become a breakthrough technology in the 21 st century. However, we can not treat it as an answer to everything. There are currently several aspects that limit its use. One of them is the lack of sufficiently efficient hardware base that could be effectively deployed on large scale block-based solutions. Organizations currently investing in blockchain also have to take into account the lack of uniformity of individual platforms for the exchange of information, and the lack of operational coherence 
[12]. This results in the fact that the transition from one platform to another - from the perspective of data, processes and skills - can prove to be extremely difficult and very costly (unprofitable).

Blockchain is a kind of computing platform identified with a distributed way of recording information about transactions. This type of technology may be the right choice when designing systems (they fit perfectly into buy and sell transactions), but other technologies will be more appropriate for many purposes. It is important to decide whether the use of blockchain is right when undertaking a design challenge. In particular, if the system is used only within one organization or organizational unit, in this case it is not recommended to build it on blockchain technology at this time [13].

\section{Summary}

As it was presented in the energy sector, the ideas of using blockchain technology have entered all subsectors from manufacturing through trade to distribution and additional services. Rapid development of dispersed energy sources - energy storage, electric cars, renewable sources such as photovoltaic panels undoubtedly contribute to the development of blockchain technology in the entire energy sector. Pro-ecological activities, such as the guarantee that the energy used comes from renewable sources, decarbonisation, rising energy costs that reduce the revenues of enterprises and the growing role of processes related to security and cyber security aspects, are also important elements for the development of blockchain technology [12].

When concluding contracts for the purchase and sale of electricity using smart contracts, transaction security is increased, legal uncertainty is eliminated and transaction costs are significantly reduced. Blockchain clearly sees its use here. With such massive contracts for the sale of energy, containing specific patterns - the technology can work perfectly, among other things because all possible inputs (amount of electricity) are known before the conclusion of the contract [4]. Nevertheless, taking the initiative to introduce technology, it is necessary to conduct a thorough and comprehensive analysis, giving the picture of the entire project.

\section{References}

1. E. Mataczyńskaka, Blockchain technology impact on the energy market model, Energy Policy Studies, Ignacy Lukasiewicz Energy Policy Institute, Rzeszów, (2017)

2. E. Vaskovskyi, Technologia blockchain - możliwości zastosowania, Ośrodek badań i analiz systemu finansowego, Alterum, (2018)

3. B. Klinger, J. Szczepański, Blockchain - historia, cechy i główne obszary zastosowań, Człowiek w cyberprzestrzeni, 1, (2017)

4. W. Szpringer, Blockchain jako innowacja systemowa, Poltext, Sp. z o. o., Warszawa (2019)

5. D. Mrowiec, M. Sołtysik, Przykładowe możliwości wykorzystania technologii blockchain w elektroenergetyce, Zeszyty Naukowe Instytutu Gospodarki Surowcami Mineralnymi i Energią Polskiej Akademii Nauk, 103, (2018)

6. V. Dhillon, D. Metcalf, M. Hooper, Zastosowanie technologii Blockchain, Wydawnictwo Naukowe PWN SA, Warszawa, (2018)

7. Por J. Reed, Smart contract: The Essential Guide to Using Blockchain Smart Contracts for Cryptocurrency Exchange, CtrateSpace Independent Publishing Platform, 2016

8. Por. K. bheemaiah, the blockchain alternative, rethinking macroeconomic policy and economic theory, Apress, (2017) 
9. Flasza J., Elektromobilność w Polsce - wyzwania i możliwości z uwzględnieniem inteligentnych instalacji OZE, Autobusy, 6, (2017)

10. Plan Rozwoju Elektromobilności w Polsce, Ministerstwo Energii, 16.03.2017

11. Ustawa o zmianie ustawy - Prawo energetyczne, ustawy - Prawo ochrony środowiska oraz ustawy o systemie oceny zgodności z dnia 12 stycznia 2007 r., Dz.U. 2007, nr 21, poz. 124

12. E. Mataczyńskaka, Technologia blockchain - możliwości, ryzyka, fakty i mity, Ignacy Lukasiewicz Energy Policy Institute, Analiza IPE, 5, (2018)

13. Risks and opportunities for systems using blockchain and smart contracts, Commonwealth Scientific and Industrial Research Organisation, (2017). 